\title{
molecules
}

ISSN 1420-3049

www.mdpi.com/journal/molecules

Article

\section{A New Sesquilignan Glucoside from Uraria sinensis}

\author{
Yingda Yang ${ }^{1}$, Zhengxi Hu ${ }^{1}$, Zengwei Luo ${ }^{1}$, Yongbo Xue ${ }^{1}$, Guangmin Yao ${ }^{1}$, Yanyan Wang ${ }^{2, *}$ \\ and Yonghui Zhang ${ }^{1, *}$
}

1 Hubei Key Laboratory of Natural Medicinal Chemistry and Resource Evaluation, School of Pharmacy, Tongji Medical College, Huazhong University of Science and Technology, Wuhan 430030, China

2 First College of Clinical Medical Science of China, Three Gorges University \& Yichang Central People’s Hospital, Yichang 443003, China

* Authors to whom correspondence should be addressed; E-Mails: wangyy1001@163.com (Y.W.); zhangyh@mails.tjmu.edu.cn (Y.Z.); Tel.: +86-717-648-7741 (Y.W.); +86-27-8369-2311 (Y.Z.); Fax: +86-27-8369-2762 (Y.W. \& Y.Z.).

Received: 26 November 2013; in revised form: 7 January 2014 / Accepted: 13 January 2014 / Published: 17 January 2014

\begin{abstract}
A new sesquilignan glucoside, urariasinoside A (1), together with eight known compounds, including two lignans, a sesquilignan, a dilignan, and four flavonoid derivatives were isolated from the aerial parts of Uraria sinensis. Their structures were determined on the basis of extensive spectroscopic analyses and comparison with literature data. Compound 1 was evaluated for in vitro cytotoxicity activity against HL-60, SMMC7721, A549, MCF-7, SW480, and BEAS-2B cell lines.
\end{abstract}

Keywords: Uraria sinensis; sesquilignan glucoside; lignans; flavonoids

\section{Introduction}

The genus Uraria (family Leguminosae), consists of 35 species, distributed throughout the tropical regions of Africa, Asia, and Australia [1]. Traditionally, some species of this genus are used as folk medicines for the treatment of gonorrhea, cough, chills and fever [2], or as therapies for swelling, coldness, ulcers and stomachalgia [3]. Pharmacological investigations have revealed that the extract of U. lagopoides has anti-inflammatory and analgesic activities [4], U. critina exerts nitric oxide-scavenging 
and antioxidant effects [5], and U. picta has antimicrobial activity [6]. Previous phytochemical studies on this genus reported the presence of isoflavanones, triterpenes, steroids, glycosides, and aromatic components [6-8]. Uraria sinensis Desv. (Hemsl.), a suffruticose sparingly branched perennial herb, is exclusively distributed in the Hubei, Sichuan, Guizhou, Yunnan, Shanxi, Gansu provinces of China [1]. To date, this species has not been investigated. As part of our ongoing search for bioactive natural compounds from the genus Uraria, we report the isolation and structure elucidation of a new sesquilignan glucoside, urariasinoside A (1), together with eight known compounds, including two lignans, a sesquilignan, a dilignan, and four flavonoid derivatives from the aerial parts of $U$. sinensis (Figure 1), as well as the inhibitory activities against five human cancer cell lines (HL-60, SMMC-7721, A549, MCF-7, and SW480) and a normal cell line (BEAS-2B) of compound 1.

Figure 1. Structures of compounds 1-9.

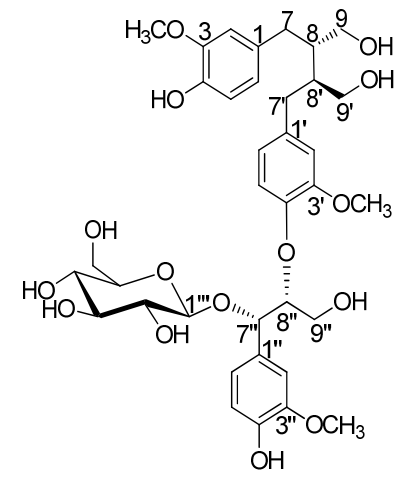<smiles>COc1cc(CC(CO)C(CO)Cc2ccc(O[C@H](CO)[C@H](O)c3ccc(O)c(OC)c3)c(OC)c2)ccc1O</smiles>

$1 \mathrm{a}$

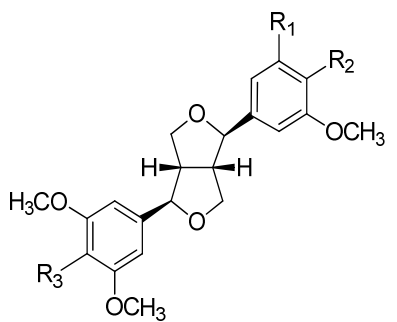

$2 \mathrm{R}_{1}=\mathrm{OCH}_{3}, \mathrm{R}_{2}=\mathrm{R}_{3}=\mathrm{OH}$ $3 \mathrm{R}_{1}=\mathrm{H}, \mathrm{R}_{2}=\mathrm{R}_{3}=\mathrm{OH}$

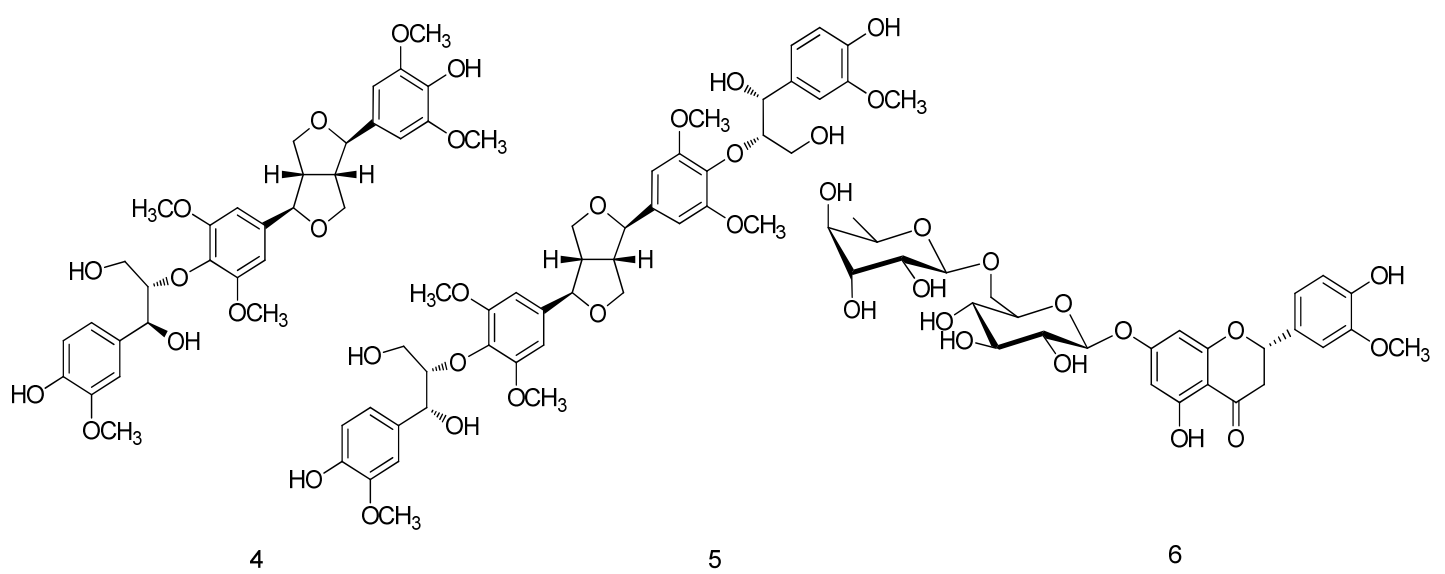<smiles>O=C1C[C@H](c2ccc(O)cc2)Oc2cc(O)cc(O)c21</smiles>

7

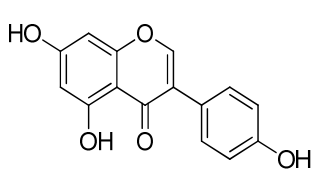

8<smiles>O=c1c(O)c(-c2ccc(O)cc2)oc2cc(O)cc(O)c12</smiles>

9

\section{Results and Discussion}

The EtOH extract of the aerial parts of $U$. sinensis was suspended in water and successively partitioned with petroleum ether, $\mathrm{CH}_{2} \mathrm{Cl}_{2}$, and $n$-butanol. The $n$-butanol-soluble extract was subjected 
to column chromatography to afford a new sesquilignan glucoside, urarisinoside A (1), along with a known compound, 5,4'-dihydroxy-3'-methoxyflavanone-7-(6" $O-\beta$-L-rhamnopyranosyl)- $\beta$-D-glucopyranoside (6) [9]. The $\mathrm{CH}_{2} \mathrm{Cl}_{2}$-soluble extract was subjected to repeated column chromatography to yield seven known compounds: (-)-syringaresinol (2) [10], (-)-medioresinol (3) [11], (-)-(7R,7'R,7"S,8S,8'S,8"S)-4',4"dihydroxy-3,3',3",5,5'-pentamethoxy-7,9':7',9-diepoxy-4,8"-oxy-8,8'-sesquineolignan-7",9"-diol (4) [12],

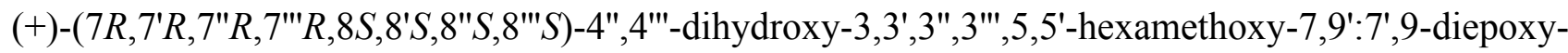
4,8":4',8'"-bisoxy-8,8'-dineolignan-7",7"',9",9"-tetraol (5) [12], naringenin (7) [13], quercetin (8) [14], and kaempferol (9) [14]. The known compounds were identified on the basis of NMR spectroscopic analyses and comparison with the data reported in the literature.

Compound 1 was obtained as pale yellow oil with the molecular formula $\mathrm{C}_{36} \mathrm{H}_{48} \mathrm{O}_{15}$, as evidenced by a pseudo-molecular ion peak $[\mathrm{M}+\mathrm{Na}]^{+}$at $\mathrm{m} / \mathrm{z} 743.2863$ in the HRESIMS spectrum. The UV spectrum suggested the existence of conjugated groups on the basis of maximum absorption bands at $228 \mathrm{~nm}$ and $280 \mathrm{~nm}$. The IR spectrum exhibited the presence of hydroxyl groups $\left(3364 \mathrm{~cm}^{-1}\right)$ and benzene rings $\left(1603 \mathrm{~cm}^{-1}\right.$ and $\left.1513 \mathrm{~cm}^{-1}\right)$. Its ${ }^{1} \mathrm{H}-\mathrm{NMR}$ spectrum (Table 1) showed three ABX spin systems assignable to three sets of 1,3,4-trisubstituted aromatic rings at $\delta_{\mathrm{H}} 6.59(1 \mathrm{H}, \mathrm{d}, J=1.1 \mathrm{~Hz})$, $6.63(1 \mathrm{H}, \mathrm{d}, J=8.0 \mathrm{~Hz})$, and $6.50(1 \mathrm{H}, \mathrm{dd}, J=8.0,1.1 \mathrm{~Hz}) ; 6.61(1 \mathrm{H}, \mathrm{d}, J=1.0 \mathrm{~Hz}), 6.70(1 \mathrm{H}, \mathrm{d}$, $J=8.1 \mathrm{~Hz})$, and $6.53(1 \mathrm{H}, \mathrm{dd}, J=8.1,1.0 \mathrm{~Hz}) ; 7.12(1 \mathrm{H}, \mathrm{d}, J=1.1 \mathrm{~Hz}), 6.74(1 \mathrm{H}, \mathrm{d}, J=8.1 \mathrm{~Hz})$, and $6.86(1 \mathrm{H}, \mathrm{dd}, J=8.1,1.1 \mathrm{~Hz})$. Its ${ }^{13} \mathrm{C}-\mathrm{NMR}$ and DEPT spectral data (Table 1) revealed the presence of 27 carbons except for the carbon signals due to a glucopyranose moiety ( $\delta \mathrm{c} 101.1,75.3,77.8,71.9$, 77.8 , and 62.8) and three methoxy groups $\left(\delta_{\mathrm{C}} 56.5,56.4\right.$, and 56.4). Subsequently, 27 carbons were assigned to a sesquilignan moiety, including three groups of aromatic carbons: nine quaternary carbons $\left(\delta_{\mathrm{C}} 151.4,149.1,148.9,147.6147 .5,145.6,136.9,133.9\right.$, and 130.5), and nine unsubstituted aromatic carbons $\left(\delta_{\mathrm{C}} 122.8,122.8,122.0,118.4,116.0,115.9,114.0,113.6\right.$, and 112.8). The remaining 9 carbons were ascribed to five methylene carbons $\left(\delta_{\mathrm{C}} 62.2,62.1,61.9,36.1\right.$, and 36.0), and four methine carbons $\left(\delta_{\mathrm{C}} 86.1,77.9,44.4\right.$, and 44.0). These before mentioned ${ }^{1} \mathrm{H}$ - and ${ }^{13} \mathrm{C}-\mathrm{NMR}$ data implied that compound 1 should be a sesquilignan glucoside.

In the ${ }^{1} \mathrm{H}-{ }^{1} \mathrm{H}$ COSY spectrum (Figure 2), the consecutive cross-peaks starting from the methylene protons at $\delta_{\mathrm{H}} 2.52(1 \mathrm{H}, \mathrm{m}, \mathrm{H}-7 \mathrm{a})$ and $2.62(1 \mathrm{H}, \mathrm{m}, \mathrm{H}-7 \mathrm{~b})$ to methine proton at $\delta_{\mathrm{H}} 1.87(1 \mathrm{H}, \mathrm{m}, \mathrm{H}-8)$, and from $\mathrm{H}-8$ to the methylene protons at $\delta_{\mathrm{H}} 3.56(1 \mathrm{H}, \mathrm{dd}, J=11.2,4.3 \mathrm{~Hz}, \mathrm{H}-9 \mathrm{a})$ and $3.82(1 \mathrm{H}$, dd, $J=11.2,5.1 \mathrm{~Hz}, \mathrm{H}-9 \mathrm{~b})$ suggested the linkage of the $\mathrm{C}_{3}$ fragment of ${ }^{7} \mathrm{CH}_{2-}{ }^{8} \mathrm{CH}_{-}{ }^{9} \mathrm{CH}_{2} \mathrm{OH}$. The ${ }^{1} \mathrm{H}-{ }^{1} \mathrm{H}$ COSY correlation of $\mathrm{CH}_{2}-7^{\prime}$ with $\mathrm{CH}-8^{\prime}$ and the correlation of $\mathrm{CH}-8^{\prime}$ with $\mathrm{CH}_{2}-9^{\prime}$ revealed the connectivity of the $\mathrm{C}_{3}$ unit ${ }^{7} \mathrm{CH}_{2-}{ }^{8}{ }^{8} \mathrm{CH}_{-}{ }^{9} \mathrm{CH}_{2} \mathrm{OH}$. Additionally, the ${ }^{1} \mathrm{H}-{ }^{1} \mathrm{H}$ COSY correlation of the oxygenated methine proton at $\delta_{\mathrm{H}} 5.17(1 \mathrm{H}, \mathrm{d}, J=4.0 \mathrm{~Hz}, \mathrm{H}-7 ")$ with the oxygenated methine proton at $\delta_{\mathrm{H}} 4.30(1 \mathrm{H}, \mathrm{m}, \mathrm{H}-8 ")$, and the correlation of $\mathrm{H}-8$ " with the oxygenated methylene protons at $\delta_{\mathrm{H}} 3.51$ $(1 \mathrm{H}, \mathrm{dd}, J=11.1,5.1 \mathrm{~Hz}, \mathrm{H}-9 " \mathrm{a})$ and $3.84(1 \mathrm{H}, \mathrm{dd}, J=11.1,4.2 \mathrm{~Hz}, \mathrm{H}-9 " \mathrm{~b})$ disclosed the fragment of the third the $\mathrm{C}_{3}$ unit ${ }^{7 "} \mathrm{CH}(\mathrm{O})-{ }^{8} \mathrm{CH}(\mathrm{O})-{ }^{9 "} \mathrm{CH}_{2} \mathrm{OH}$. These three $\mathrm{C}_{3}$ units were connected to the above three sets of 1,3,4-trisubstituted phenyl groups respectively, according to the HMBC correlations (Figure 2) of H-7 with C-1, C-2, and C-6; of H-7' with C-1', C-2', and C-6'; and of H-7" with C-1", C-2", and C-6". 
Table 1. ${ }^{1} \mathrm{H}-\mathrm{NMR}(400 \mathrm{MHz})$ and ${ }^{13} \mathrm{C}-\mathrm{NMR}(100 \mathrm{MHz})$ data of compound 1 (in $\mathrm{CD}_{3} \mathrm{OD}, \delta$ in ppm, $J$ in $\mathrm{Hz}$ ).

\begin{tabular}{|c|c|c|c|c|c|}
\hline NO. & $\delta_{\mathrm{H}}$ & $\delta_{\mathrm{C}}$ & NO. & $\delta_{\mathrm{H}}$ & $\delta_{\mathrm{C}}$ \\
\hline 1 & - & 133.9 & $9^{\prime} b$ & $3.56 \mathrm{dd}(11.2,4.3)$ & - \\
\hline 2 & $6.59 \mathrm{~d}(1.1)$ & 113.6 & $1 "$ & - & 130.5 \\
\hline 3 & - & 149.1 & $2^{\prime \prime}$ & $7.12 \mathrm{~d}(1.1)$ & 112.8 \\
\hline 4 & - & 145.6 & $3 "$ & - & 148.9 \\
\hline 5 & $6.63 \mathrm{~d}(8.0)$ & 116.0 & $4 "$ & - & 147.6 \\
\hline 6 & $6.50 \mathrm{dd}(8.0,1.1)$ & 122.8 & $5^{\prime \prime}$ & $6.74 \mathrm{~d}(8.1)$ & 115.9 \\
\hline $7 \mathrm{a}$ & $2.52 \mathrm{~m}$ & 36.0 & 6" & $6.86 \mathrm{dd}(8.1,1.1)$ & 122.0 \\
\hline $7 \mathrm{~b}$ & $2.62 \mathrm{~m}$ & - & $7 "$ & $5.17 \mathrm{~d}(4.0)$ & 77.9 \\
\hline 8 & $1.87 \mathrm{~m}$ & 44.0 & $8 "$ & $4.30 \mathrm{~m}$ & 86.1 \\
\hline $9 \mathrm{a}$ & $3.56 \mathrm{dd}(11.2,5.1)$ & 62.1 & $9 " \mathrm{a}$ & $3.51 \mathrm{dd}(11.1,5.1)$ & 61.9 \\
\hline $9 b$ & $3.82 \mathrm{dd}(11.2,4.3)$ & - & 9"b & $3.84 \mathrm{dd}(11.1,4.2)$ & - \\
\hline $1^{\prime}$ & - & 136.9 & Glc-1"' & $4.15 \mathrm{~d}(7.4)$ & 101.1 \\
\hline $2^{\prime}$ & $6.61 \mathrm{~d}(1.0)$ & 114.0 & $2 " '$ & $3.32 \mathrm{dd}(8.9,7.4)$ & 75.3 \\
\hline $3^{\prime}$ & - & 151.4 & 3"' & $3.27 \mathrm{t}(8.9)$ & 77.8 \\
\hline $4^{\prime}$ & - & 147.5 & $4 " '$ & $3.28 \mathrm{~m}$ & 71.9 \\
\hline $5^{\prime}$ & $6.70 \mathrm{~d}(8.1)$ & 118.4 & $5^{\prime \prime \prime}$ & $3.11 \mathrm{~m}$ & 77.8 \\
\hline $6^{\prime}$ & $6.53 \mathrm{dd}(8.1,1.0)$ & 122.8 & $6 " \mathrm{a}$ & $3.66 \mathrm{dd}(11.8,4.5)$ & 62.8 \\
\hline $7{ }^{\prime} \mathrm{a}$ & $2.52 \mathrm{~m}$ & 36.1 & 6"'b & $3.83 \mathrm{dd}(11.8,2.3)$ & - \\
\hline $7 \mathrm{~b}$ & $2.62 \mathrm{~m}$ & - & $3-\mathrm{OCH}_{3}$ & $3.69 \mathrm{~s}$ & 56.4 \\
\hline $8^{\prime}$ & $1.86 \mathrm{~m}$ & 44.4 & $3^{\prime}-\mathrm{OCH}_{3}$ & $3.69 \mathrm{~s}$ & 56.4 \\
\hline $9^{\prime} \mathrm{a}$ & $3.52 \mathrm{dd}(11.2,5.1)$ & 62.2 & 3"--OCH & $3.76 \mathrm{~s}$ & 56.5 \\
\hline
\end{tabular}

Figure 2. Key HMBC and ${ }^{1} \mathrm{H}-{ }^{1} \mathrm{H}$ COSY correlations of compound $\mathbf{1}$.

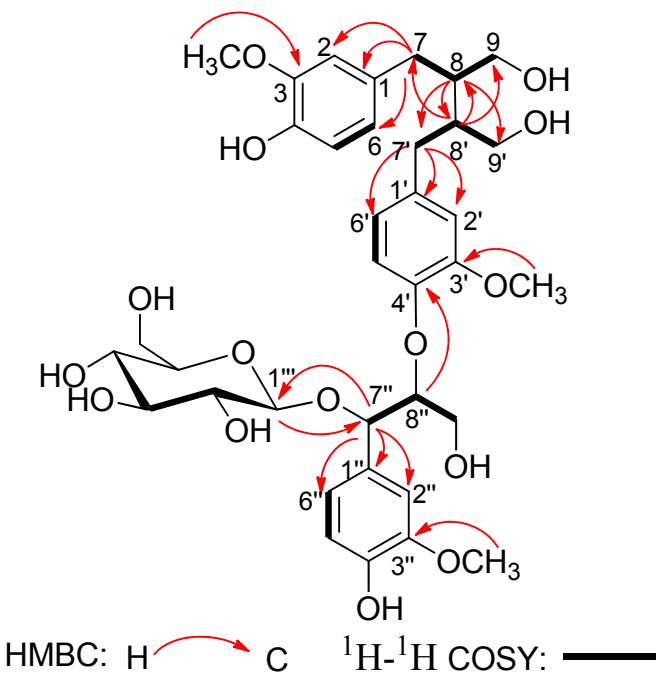

Moreover, the HMBC correlation (Figure 2) between H-8" and C-4' verified ether linkage between C-8" and C-4'. Meanwhile, the C-8/C-8' linkage was confirmed by HMBC correlations of H-8 with C-7', C-8' and C-9', and of H-8' with C-7, C-8 and C-9 in the HMBC spectrum. The signals due to methoxy protons were assigned as $3-\mathrm{OCH}_{3}, 3^{\prime}-\mathrm{OCH}_{3}$, and 3 "- $-\mathrm{OCH}_{3}$, on the basis of the cross-peaks from $\mathrm{H}-3-\mathrm{OCH}_{3}$ to $\mathrm{C}-3, \mathrm{H}-3$ '- $\mathrm{OCH}_{3}$ to $\mathrm{C}-3$ ', and $\mathrm{H}-3$ "- $-\mathrm{OCH}_{3}$ to $\mathrm{C}-3$ " according to the HMBC spectrum. 
The position of 3- $\mathrm{OCH}_{3}, 3$ '- $-\mathrm{OCH}_{3}$, and 3"- $-\mathrm{OCH}_{3}$ was also corroborated by the correlations between $\mathrm{H}-3-\mathrm{OCH}_{3}$ and $\mathrm{H}-2, \mathrm{H}-3$ '-OCH 3 and $\mathrm{H}-2$ ', and $\mathrm{H}-3$ "- $-\mathrm{OCH}_{3}$ and $\mathrm{H}-2$ " in the NOESY spectrum (Figure 3). Thus, all the information mentioned above suggested that compound $\mathbf{1}$ was a secoisolariciresinolsesquilignan derivative related to sesquimarocanol $\mathrm{B}[15,17,18]$.

Figure 3. Key NOESY correlations of compound $\mathbf{1}$.

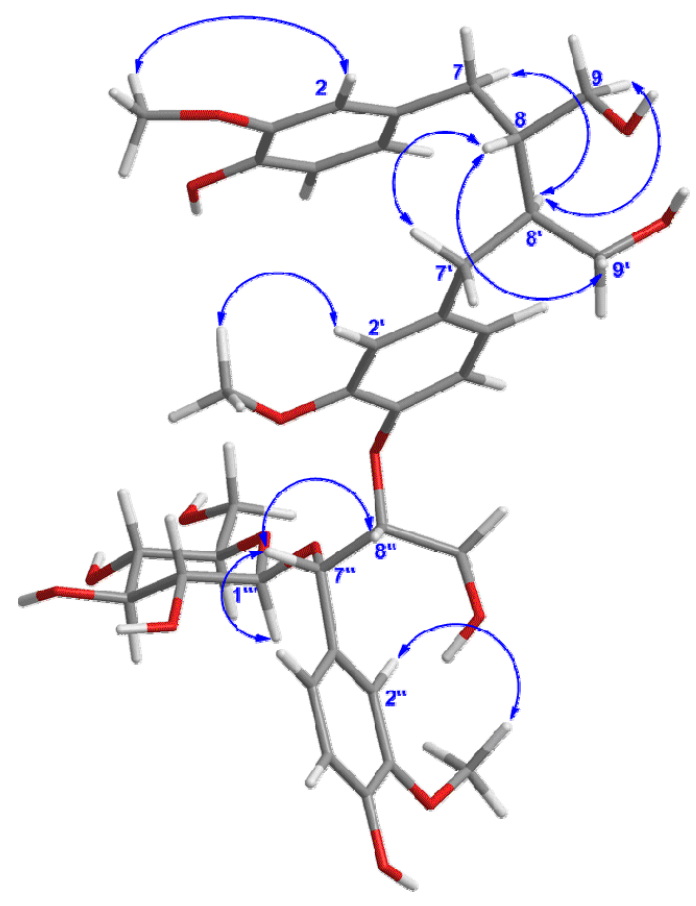

The remaining proton signals from $\delta_{\mathrm{H}} 3.83$ to 3.32 in the ${ }^{1} \mathrm{H}-\mathrm{NMR}$ spectrum disclosed a set of $\beta$ glucopyranose moiety with the anomeric proton resonated at $\delta_{\mathrm{H}} 4.15\left(1 \mathrm{H}, \mathrm{d}, J=7.4 \mathrm{~Hz}, \mathrm{H}-1^{\prime \prime \prime}\right)$, corresponding to six carbon signals at $\delta \mathrm{c} 101.1,75.3,77.8,71.9,77.8,62.8$ in ${ }^{13} \mathrm{C}-\mathrm{NMR}$ spectrum. The $\beta$-glucose was located at C-7" as elucidated by the HMBC correlation between $\mathrm{Glc}-\mathrm{H}-1$ '" and the oxygenated methine carbon C-7", which was further confirmed by the NOESY correlation between H-1"' and H-7". Herein, 1 was identified as a secoisolariciresinol-sesquilignan glucoside. Furthermore, the presence of $\beta$-D-glucose was determined by $\mathrm{GC}$ analysis of its trimethylsilyl thiazolidine derivative after acid hydrolysis [16].

The relative configuration of 1 was elucidated by the NOESY (Figure 3) experiment, together with comparison with data of sesquimarocanol B. Likewise, the NOESY correlations of H-8' with H-7 and H-9, of H-8-with H-7' and H-9', and the absence of the NOESY cross-peak between H-8 and H-8', pointed to the trans orientations for $\mathrm{H}-8 / \mathrm{H}-8^{\prime}$ as that of sesquimarocanol B. Similarly, the relative stereochemistry of $\mathrm{H}-7 " / \mathrm{H}-8$ " was supposed to cis configuration according to the correlation between $\mathrm{H}-7$ " and H-8".

Enzymatic hydrolysis of $\mathbf{1}$ by the cellulase liberated an aglycon 1a, which had the molecular $\mathrm{C}_{30} \mathrm{H}_{38} \mathrm{O}_{10}$, as deduced from HRESIMS at $\mathrm{m} / z$ 581.2344 [M+Na] $]^{+}$The NMR data of 1a was very similar with that of sesquimarocanol B [15]. However, the coupling constants of $\mathrm{H}-7 \mathrm{7} / \mathrm{H}-8$ " for $\mathbf{1 a}$ and sesquimarocanol B were obviously different. In sesquimarocanol B, a large coupling constant $(J=6.3 \mathrm{~Hz})$ suggested the threo configuration of $\mathrm{H}-7 " / \mathrm{H}-8^{\prime \prime}$ [17]. Whereas in 1a, a small coupling constant $(J=4.0 \mathrm{~Hz})$ of $\mathrm{H}-7 " / \mathrm{H}-8$ ", and the proton signal of $7 "$ at $\delta_{\mathrm{H}} 4.88$ further confirmed an erythro configuration 
between H-7"/H-8" in 1, as a stereoisomer of sesquimarocanol B [19-21]. In addition, the absolute configuration of C-8" was determined to be $R$, as the CD spectrum showed a negative Cotton effect at $239 \mathrm{~nm}$ [22-24]. Correspondingly, the absolute configuration of 7" was elucidated as $S$. Finally, the structure of 1 was determined to be (7"S,8"R)-(-)-4,4",9,9',9"-pentahydroxy-3,3',3"-trimethoxy-4',8"oxy-8,8'-sesquineolignan-7"- $O$ - $\beta$-D-glucopyranoside, to which the trivial name urariasinoside A was assigned.

In the other respects, previous reports of cytotoxicity activity of secoisolariciresinol-sesquilignan related structures such as sesquimarocanol B hexaacetate [16], suggest compound $\mathbf{1}$ might have potential activity as an anticancer agent. Therefore, compound $\mathbf{1}$ was evaluated for its cytotoxic activities against five human cancer cell lines: HL-60 (human myeloid leukemia), SMMC-7721 (hepatocellular carcinoma), A549 (lung), MCF-7 (breast), and SW480 (colon) by the MTT method [25]. DDP (cisplatin) and taxol were used as positive controls. However, the bioassay results revealed that compound 1 has no in vitro cytotoxicity $\left(\mathrm{IC}_{50}>40 \mu \mathrm{M}\right)$ against any of the five tested cancer cell lines.

\section{Experimental}

\subsection{General Procedures}

Optical rotations were measured on a Perkin Elmer PE-341LC polarimeter. UV spectra were measured on a Perkin Elmer Lambda 35 spectrometer. CD spectra were recorded on a JASCO J-810 CD spectrometer. IR spectra were recorded on a Bruker Vertex 70 FT-IR microscope instrument (FT-IRmicroscope transmission). NMR spectra were obtained at $400 \mathrm{MHz}$ for ${ }^{1} \mathrm{H}$ and 100 for ${ }^{13} \mathrm{C}$, on Bruker AM-400 MHz spectrometers with solvent peaks being used as references. Two-dimensional HSQC, HMBC, COSY, and NOESY experiments were performed using the pulse sequences provided by Bruker. HRESIMS data were measured using an API QSTAR Pulsar spectrometer. Column chromatography was performed using polyamide (10-30 mesh, Taizhou Luqiao Sijia Biochemical Plastics Factory, Taizhou, China), silica gel (100-200, 200-300 mesh, H, Qingdao Marine Chemical Inc., China), ODS (50 $\mu \mathrm{m}$, YMC, Kyoto, Japan) and Sephadex LH-20 (Pharmacia Biotech AB, Uppsala Sweden). HPLC separation was performed on an instrument consisting of an Ultimate 3000 controller, an Ultimate 3000 pump, and an Ultimate $3000 \mathrm{UV}$ detector with an YMC $(250 \times 10 \mathrm{~mm}, 5$ $\mu \mathrm{m})$ preparative column. GC analysis was performed on an Agilent Technologies 7820A GC instrument, OV-17 column $(30 \mathrm{~m} \times 0.32 \mathrm{~mm} \times 0.5 \mu \mathrm{m}$, Lanzhou Zhongke Antai Analysis Technology Co. Ltd., Lanzhou, China), hydrogen-flame ionization detector. Enzymatic hydrolysis was treated with cellulase (Shanghai Yuanye Biology \& Technology Co. Ltd., Shanghai, China). TLC was carried out on precoated silica gel GF254 plates. Spots were visualized under UV light (254 or $356 \mathrm{~nm}$ ) or by spraying with $5 \% \mathrm{H}_{2} \mathrm{SO}_{4}$ in $95 \% \mathrm{EtOH}$ followed by heating.

\subsection{Plant Material}

The aerial parts of $U$. sinensis were collected from Shiyan, Hubei Province, China in September 2010 and identified by Dr. Jianping Wang of School of Pharmacy, Tongji Medical College, Huazhong University of Science and Technology. The voucher specimen (1009) was deposited in the herbarium 
of Hubei Key Laboratory of Natural Medicinal Chemistry and Resource Evaluation, School of Pharmacy, Tongji Medical College, Huazhong University of Science and Technology.

\subsection{Extraction and Isolation}

The air-dried aerial parts of $U$. sinensis $(45 \mathrm{~kg})$ were extracted three times with $95 \% \mathrm{EtOH}(50 \mathrm{~L})$ at room temperature for $24 \mathrm{hThe}$ dried $\mathrm{EtOH}$ extract $\left(4.0 \mathrm{~kg}\right.$ ) was suspended in $\mathrm{H}_{2} \mathrm{O}$ and then partitioned successively with petroleum ether $(10.0 \mathrm{~L} \times 3), \mathrm{CH}_{2} \mathrm{Cl}_{2}(10.0 \mathrm{~L} \times 3)$ and $n-\mathrm{BuOH}(10.0 \mathrm{~L} \times 3)$. The $n$-butanol portion (375 g) was fractionated by column chromatography over polyamide $(6 \mathrm{Kg})$ using $\mathrm{H}_{2} \mathrm{O}-\mathrm{EtOH}$ of increasing polarity $(100: 0(50 \mathrm{~L} \times 3), 10: 90(50 \mathrm{~L} \times 3), 30: 70(50 \mathrm{~L} \times 3), 0: 100(50 \mathrm{~L} \times 3)$, $v / v)$. The eluates were combined together on the basis of TLC analysis. Then, the fractions eluted with pure water (the extract $172 \mathrm{~g}$ ) were further subjected to silica gel column chromatography $\left(\mathrm{CHCl}_{3}-\mathrm{MeOH}-\mathrm{H}_{2} \mathrm{O}\right.$ 15:1:0 to 3:1:0.1, v/v/v) to afford seven fractions (Fr.1-7). Fr.6 (11.7 g) was subjected to silica gel column chromatography $\left(\mathrm{CHCl}_{3}-\mathrm{MeOH}-\mathrm{H}_{2} \mathrm{O}\right.$ 5:1:0.1 to 3:1:0.1, v/v/v) once again to give four subfractions (Fr.6.1-6.4). Fr.6.3 was subjected to a Sephadex LH-20 column eluted with $\mathrm{MeOH}$ to give six subfractions (Fr.6.3.1-6.3.6). Fr.6.3.4 was purified by silica gel H column chromatography $\left(\mathrm{CHCl}_{3}-\mathrm{MeOH}-\mathrm{H}_{2} \mathrm{O}\right.$ 3:1:0.1, v/v/v) to obtain compound 6 (10.5 mg). Fr.6.3.3 was subjected to ODS column chromatography eluted with $50 \% \mathrm{MeOH}$ in $\mathrm{H}_{2} \mathrm{O}$, and then purified by semi-preparative HPLC $\left(37 \% \mathrm{MeOH}\right.$ in $\mathrm{H}_{2} \mathrm{O}$, flow rate $1.8 \mathrm{~mL} / \mathrm{min}$, wavelength $\left.212 \mathrm{~nm}\right)$ to yield compound 1 (5.0 $\mathrm{mg}$, retention time $37 \mathrm{~min}$ ).

The $\mathrm{CH}_{2} \mathrm{Cl}_{2}$ extract (150 g) was applied to silica gel column chromatography eluted with petroleum ether-acetone $(10: 1$ to $1: 1, v / v)$ to afford ten fractions (Fr.A-J). Compound $10(20.0 \mathrm{mg})$ was recrystallized from Fr.G using acetone. Fr.G $(5.1 \mathrm{~g})$ was subjected to silica gel column chromatography $\left(\mathrm{CHCl}_{3}-\mathrm{MeOH} 20: 1\right.$ to $\left.8: 1, v / v\right)$ to afford seven subfractions $\left(\mathrm{Fr} . \mathrm{G}_{1}-\mathrm{G}_{7}\right)$. Fr. $\mathrm{G}_{3}$ and Fr.G $\mathrm{G}_{5}$ were subjected to a Sephadex LH-20 column eluted with $\mathrm{CH}_{2} \mathrm{Cl}_{2}-\mathrm{MeOH}(1: 1, v / v)$ to give compound $8(16.4 \mathrm{mg})$ by recrystallization. Compound $9(14.5 \mathrm{mg})$ was obtained by recrystallization in acetone from Fr. $\mathrm{G}_{3}$.

Fr.H (20.0 g) was subjected to silica gel column chromatography $\left(\mathrm{CHCl}_{3}-\mathrm{MeOH} 30: 1\right.$ : to 8:1, v/v) to afford eight subfractions $\left(\mathrm{Fr} . \mathrm{H}_{1}-\mathrm{H}_{8}\right)$. Fr. $\mathrm{H}_{2}$ was applied to $\mathrm{MCI}$ gel column eluted with $\mathrm{MeOH} / \mathrm{H}_{2} \mathrm{O}$ $(8: 1, v / v)$, and then was subjected to a Sephadex LH-20 column eluted with $\mathrm{MeOH}$ to give seven subfractions (Fr. $\left.\mathrm{H}_{2.1-2.7}\right)$. Fr. $\mathrm{H}_{2.2}$ was further purified by semi-preparative HPLC (MeOH-MeCN- $\mathrm{H}_{2} \mathrm{O}$ 35:15:50, flow rate $2.5 \mathrm{~mL} / \mathrm{min}$, wavelength $254 \mathrm{~nm}$ ) to yield compound 2 (17.5 $\mathrm{mg}$, retention time 20 $\mathrm{min})$ and compound $3(8.0 \mathrm{mg}$, retention time $23 \mathrm{~min})$.

Fr.I (6.0 g) was subjected to silica gel column chromatography $\left(\mathrm{CHCl}_{3}-\mathrm{MeOH} 15: 1:\right.$ to $\left.7: 1, v / v\right)$ to afford nine subfractions (Fr. $\mathrm{I}_{1}-\mathrm{I}_{9}$ ). Fr. $\mathrm{I}_{1}$ was subjected to a Sephadex LH-20 column eluted with $\mathrm{CH}_{2} \mathrm{Cl}_{2}-\mathrm{MeOH}(1: 1, v / v)$ to give four subfractions (Fr.I $\left.\mathrm{I}_{1.1-1.4}\right)$. Fr.I $\mathrm{I}_{1.2}$ was subjected to ODS column chromatography eluted with $50 \% \mathrm{MeOH}$ in $\mathrm{H}_{2} \mathrm{O}$, and then purified by semi-preparative HPLC ( $\mathrm{MeOH}-\mathrm{MeCN}-\mathrm{H}_{2} \mathrm{O}$ 20:18:62, flow rate $2.5 \mathrm{~mL} / \mathrm{min}$, wavelength $212 \mathrm{~nm}$ ) to yield compound 4 (7.2 $\mathrm{mg}$, retention time $58 \mathrm{~min})$.

Fr.J (25.0 g) was subjected to silica gel column chromatography $\left(\mathrm{CHCl}_{3}-\mathrm{MeOH} 12: 1\right.$ to $\left.8: 1, v / v\right)$ to afford four subfractions $\left(\mathrm{Fr} . \mathrm{J}_{1}-\mathrm{J}_{8}\right)$. Fr. $\mathrm{J}_{2}$ was subjected to a Sephadex LH-20 column eluted with $\mathrm{CH}_{2} \mathrm{Cl}_{2}-\mathrm{MeOH}(1: 1, v / v)$ to remove chlorophyll, and then further subjected to ODS column 
chromatography eluted with $50 \% \mathrm{MeOH}$ in $\mathrm{H}_{2} \mathrm{O}$ to give two subfractions (Fr.J $\mathrm{J}_{2.1-2.2}$ ). Fr.J $\mathrm{J}_{2.1}$ was subjected to silica gel column chromatography $\left(\mathrm{CHCl}_{3}-\mathrm{Me}_{2} \mathrm{CO}-\mathrm{MeOH}\right.$ 30:15:0.1, v/v/v) and then purified by semi-preparative HPLC (MeOH-MeCN- $\mathrm{H}_{2} \mathrm{O}$ 29:21:50, flow rate $2 \mathrm{~mL} / \mathrm{min}$, wavelength $254 \mathrm{~nm}$ ) to yield compound $\mathbf{5}$ (2.3 $\mathrm{mg}$, retention time $30 \mathrm{~min})$.

Urariasinoside A [(7"S,8"R)-(-)-4,4",9,9',9"-pentahydroxy-3,3',3"-trimethoxy-4',8"-oxy-8, 8'-sesquineolignan-7"-O- $\beta$-D-glucopyranoside] (1). Pale yellow oil. $[\alpha]_{\mathrm{D}}^{20}:-29$ (c =0.79, MeOH); UV (MeOH) $\lambda_{\max }(\log \varepsilon) \mathrm{nm}: 280$ (3.32), 228 (3.68), 207 (4.03); CD (MeOH, nm) $\lambda_{\max }(\Delta \varepsilon) 211(+11.48), 229$ $(+1.30), 239(-3.74), 281(+2.71), 297(+1.37), 322(+1.83)$; IR $(\mathrm{KBr}) v_{\max } 3364,2935,1603,1513$, 1453, 1423, 1369, 1268, 1224, 1155, 1127, 1075, $1029 \mathrm{~cm}^{-1} ;{ }^{1} \mathrm{H}-$ and ${ }^{13} \mathrm{C}-\mathrm{NMR}$ : see Table 1; HRESIMS m/z: $743.2863\left([\mathrm{M}+\mathrm{Na}]^{+}, \mathrm{C}_{36} \mathrm{H}_{48} \mathrm{O}_{15} \mathrm{Na}^{+}\right.$, calc. 743.2891).

\subsection{Determination of the Absolute Configuration of Sugar Unit in $\mathbf{1}$}

A solution of $1(1.0 \mathrm{mg})$, in $2 \mathrm{M}$ aqueous $\mathrm{CF}_{3} \mathrm{COOH}(2.0 \mathrm{~mL})$ was heated at $100{ }^{\circ} \mathrm{C}$ for $3 \mathrm{~h}$ in a water bath. The reaction mixture was diluted in $\mathrm{H}_{2} \mathrm{O}(4.0 \mathrm{~mL})$ and extracted with EtOAc $(4.0 \mathrm{~mL} \times 3)$, then the aqueous layer was concentrated to remove $\mathrm{CF}_{3} \mathrm{COOH}$. The residue was dissolved in pyridine $(1.0 \mathrm{~mL})$, to which L-cysteine methyl ester hydrochloride $(2.0 \mathrm{mg})$ in pyridine $(1.0 \mathrm{~mL})$ was added. Then, the mixture was kept at $60{ }^{\circ} \mathrm{C}$ for $2 \mathrm{~h}$. After the reaction mixture was dried in vacuo, the residue was trimethylsilylated with 1-trimethylsilylimidazole $(0.2 \mathrm{~mL})$ at $60^{\circ} \mathrm{C}$ for $2 \mathrm{~h}$ in a water bath. Finally, the mixture was partitioned between hexane and $\mathrm{H}_{2} \mathrm{O}(0.3 \mathrm{~mL}$ each) and the hexane extract was analyzed by gas chromatography (GC) under the following conditions: column temperature, $250{ }^{\circ} \mathrm{C}$; injection temperature, $250{ }^{\circ} \mathrm{C}$; carrier $\mathrm{N}_{2}$ gas; flow rate $1.0 \mathrm{~mL} / \mathrm{min}$. In the acid hydrolysate of $\mathbf{1}$, D-Glucose was confirmed by comparison of the retention times of their derivatives with those of D-glucose and L-glucose derivatives prepared in a similar way, which showed retention times of 13.66 and $14.34 \mathrm{~min}$, respectively.

\subsection{Enzymatic Hydrolysis of 1}

A solution of $1(2.67 \mathrm{mg})$ in $0.1 \mathrm{M}$ acetate buffer $(\mathrm{pH} 4.0,2.0 \mathrm{~mL})$ was treated with cellulase $(3.0 \mathrm{mg})$ and then the reaction mixture was stirred at $40{ }^{\circ} \mathrm{C}$ for $12 \mathrm{~h}$. The reaction mixture was diluted in $\mathrm{H}_{2} \mathrm{O}$ $(4.0 \mathrm{~mL})$ and extracted with EtOAc $(4.0 \mathrm{~mL} \times 3)$. After that, the EtOAc extract was further purified by semi-preparative $\mathrm{HPLC}\left(50 \% \mathrm{MeOH}\right.$ in $\mathrm{H}_{2} \mathrm{O}$, flow rate $1.8 \mathrm{~mL} / \mathrm{min}$, wavelength $\left.212 \mathrm{~nm}\right)$ to obtain compounds $\mathbf{1 a}(1.2 \mathrm{mg}$, retention time $18.3 \mathrm{~min})$.

Erythro-(-)-secoisolariciresinol-sesquilignan (1a). Pale yellow oil. $[\alpha]_{\mathrm{D}}^{20}:-7.1(c=0.028, \mathrm{MeOH})$; ${ }^{1} \mathrm{H}-\mathrm{NMR}\left(\mathrm{CD}_{3} \mathrm{OD}, 400 \mathrm{MHz}\right) \delta_{\mathrm{H}}: 7.03(1 \mathrm{H}, \mathrm{d}, J=1.8 \mathrm{~Hz}, 2 "-\mathrm{H}), 6.93(1 \mathrm{H}, \mathrm{d}, J=8.2 \mathrm{~Hz}, 5 "-\mathrm{H}), 6.86$ $(1 \mathrm{H}, \mathrm{dd}, J=8.2,1.8 \mathrm{~Hz}, 6 "-\mathrm{H}), 6.76(1 \mathrm{H}, \mathrm{d}, J=8.1 \mathrm{~Hz}, 5-\mathrm{H}), 6.68(1 \mathrm{H}, \mathrm{d}, J=1.8 \mathrm{~Hz}, 2-\mathrm{H}), 6.66(1 \mathrm{H}$, d, $\left.J=8.0 \mathrm{~Hz}, 5^{\prime}-\mathrm{H}\right), 6.64\left(1 \mathrm{H}, \mathrm{d}, J=1.9 \mathrm{~Hz}, 2^{\prime}-\mathrm{H}\right), 6.63(1 \mathrm{H}, \mathrm{dd}, J=8.1,1.8 \mathrm{~Hz}, 6-\mathrm{H}), 6.54$ (1H, dd, $J$ $\left.=8.0,1.9 \mathrm{~Hz}, 66^{\prime}-\mathrm{H}\right), 4.88(1 \mathrm{H}, \mathrm{d}, J=4.0 \mathrm{~Hz}, 7 "-\mathrm{H}), 4.20\left(1 \mathrm{H}, \mathrm{m}, 8^{\prime \prime}-\mathrm{H}\right), 3.86(1 \mathrm{H}, \mathrm{d}, J=11.5 \mathrm{~Hz}$, 9"-Ha), $3.82(3 \mathrm{H}, \mathrm{s}, 3$ "-OCH $), 3.77\left(3 \mathrm{H}, \mathrm{s}, 3-\mathrm{OCH}_{3}\right), 3.75\left(3 \mathrm{H}, \mathrm{s}, 3^{\prime}-\mathrm{OCH}_{3}\right), 3.72(1 \mathrm{H}, J=11.5,4.1$ Hz, 9"-Hb), 3.69 (1H, overlapped, 9-Hb), 3.58 (2H, m, 9-Ha, 9'-Hb), $3.46(1 \mathrm{H}, \mathrm{dd}, J=11.8,5.2 \mathrm{~Hz}$, 
9'-Ha), 2.67 (2H, m, 7,7'-Ha), 2.60 (2 H, m, 7, 7'-Hb ), 2.06 (2H, m, 8,8'-H); HRESIMS m/z: 581.2344 $\left([\mathrm{M}+\mathrm{Na}]^{+}, \mathrm{C}_{30} \mathrm{H}_{38} \mathrm{O}_{10} \mathrm{Na}^{+}\right.$, calc. 581.2363).

\subsection{MTT Cytotoxicity Assay}

Compound 1 was tested against five human cancer cell lines [HL-60 and SMMC-7721, A549 (lung), MCF-7 (breast), and SW480 (colon)] and a normal cell line (BEAS-2B). The antiproliferative assay was performed by the MTT colorimetric method as described previously [25]. Briefly, adherent cells were seeded into 96-well tissue culture plates with density of $1 \times 10^{5}$ cells $/ \mathrm{mL}$. After $12 \mathrm{~h}$, cells were treated with the medium containing different concentrations of test compounds for $48 \mathrm{~h}$. Then, attached cells were incubated with MTT $(15 \mu \mathrm{L}, 5 \mathrm{mg} / \mathrm{mL}, 1 \mathrm{~h})$ and subsequently solubilized in DMSO. The optical density of absorbency at $595 \mathrm{~nm}$ was then measured using a microplate reader. Experiments were performed in triplicate, and the values are the averages of three $(n=3)$ independent experiments. DDP (cisplatin, Sigma, San Francisco, CA, USA) and taxol were used as the positive control.

\section{Conclusions}

Studies carried out on the EtOH extracts of $U$. sinensis, revealed the presence of a new sesquilignan glucoside, urariasinoside A (1), was isolated from the aerial parts of $U$. sinensis together with eight known compounds, including two lignans (-)-syringaresinol (2), (-)-medioresinol (3); a sesquilignan (-)-(7R,7'R,7"S,8S,8'S,8"S)-4',4"-dihydroxy-3,3',3",5,5'-pentamethoxy-7,9':7',9-diepoxy-4,8''-oxy-8,8'-

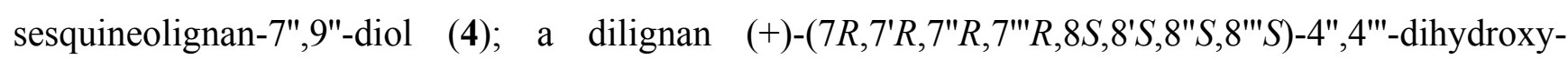
3,3',3",3"',5,5'-hexamethoxy-7,9':7',9-diepoxy-4,8":4',8"'-bisoxy-8,8'-dineolignan-7",7"',9",9"'-tetraol (5), and four flavonoids derivatives 5,4'-dihydroxy-3'-methoxyflavanone-7-(6"-O- $\beta$-L-rhamnopyranosyl)- $\beta$ D-glucopyranoside (6), naringenin (7), quercetin (8), and kaempferol (9). Compounds 2-9 were isolated from $U$. sinensis for the first time. Cytotoxicity assays revealed that compound $\mathbf{1}$ was inactive $\left(\mathrm{IC}_{50}>40 \mu \mathrm{M}\right)$ against the HL-60, SMMC-7721, A549, MCF-7, and SW480 cell lines.

\section{Supplementary Materials}

Supplementary materials can be accessed at: http://www.mdpi.com/1420-3049/19/1/1178/s1.

\section{Acknowledgments}

We gratefully acknowledge financial support of this work by the National Natural Science Foundation of China (No. 30970297, 31270390), National Science and Technology Major Project of China (No. 2011ZX09102-006-05).

\section{Author Contributions}

All listed authors contributed to this work. Yingda Yang was responsible for the extraction, isolation and identification of the pigments, and preparation of the manuscript; Zhengxi Hu contributed to perform the MTT cytotoxicity assay; Zengwei Luo, Yongbo Xue, and Guangmin Yao were responsible for the enzymatic hydrolysis reaction and the structure elucidation of new compound; 
Yanyan Wang and Yonghui Zhang contributed equally to the work as the corresponding authors who designed and obtained financial support.

\section{Conflicts of Interest}

The authors declare no conflict of interest.

\section{References}

1. Hutchinson, J. The Genera of Flowering Plants; Clarendo Press: Oxford, England, 1964; pp. 481-482.

2. Wang, J.W. Kenyan and Indian medicinal plants. Foreign Med. Sci. 2003, 25, 122.

3. Liu, S.Y.; Liou, P.C.; Wang, J.Y.; Shyu, Y.T.; Hu, M.F.; Chang, Y.M.; Shieh, J.I. Production and Electrophoretic Analysis of Medical Plants in Taiwan; Taiwan Agricultural Research Institute special publication: Taichung, Taiwan, 1995; pp. 149-188.

4. Hamid, F.; Abdullah, S.T.; Ali, A.; Alam, M.S.; Ansari, S.H. Antiinflammatory and analgesic activity of Uraria lagopoides. Pharm. Biol. 2004, 42, 114-116.

5. Yen, G.C.; Lai, H.H.; Chou, H.Y. Nitric oxide-scavenging and antioxidant effects of Uraria. crinita root. Food Chem. 2001, 74, 471-478.

6. Rahman, M.M.; Simon, G.; Alexander, I.G. Isoflavanones from Uraria picta and their antimicrobial activity. Phytochemistry 2007, 68, 1692-1697.

7. Chen, Y.; Si, X.L.; Wei, S.; Xu, X.J. Studies on chemical constituents of Uraria legopodioides. Chin. Tradit. Pat. Med. 2009, 31, 266-269.

8. Wang, Y.Y.; Zhang, X.Q.; Gong, L.M.; Ruan, H.L.; PI, H.F.; Zhang, Y.H. Studies on chemical constituents in roots of Uraria crinita. Chin. Pharm. J. 2009, 44, 1217-1220.

9. Chen, Y.; Liu, J.; Davidson, S.R.; Howarth, O.W. Isolation and structure of clematine, a new flavanone glycoside from Clematis armandii franch. Tetrahedron 1993, 49, 5169-5176.

10. Quyang, M.A.; Wein, Y.S.; Zhang, Z.K.; Kuo, Y.H. Inhibitory activity against tobacco mosaic virus (TMV) replication of pinoresinol and syringaresinollignans and their glycosides from the root of Rhus javanica var. roxburghiana. J. Agric. Food. Chem. 2007, 55, 6460-6465.

11. Li, N.; Wu, J.; Hasegawa, T.; Sakai, J.; Bai, L.; Wang, L.; Kakuta, S.; Furuya, Y.; Ogura, H.; Kataoka, T. Bioactive lignans from Peperomia duclouxii. J. Nat. Prod. 2007, 70, 544-548.

12. Xiong, L.; Zhu, C.; Li, Y.; Tian, Y.; Lin, S.; Yuan, S.; Hu, J.; Hou, Q.; Chen, N.; Yang, Y. Lignans and neolignans from Sinocalamus affinis and their absolute configurations. J. Nat. Prod. 2011, 74, 1188-1200.

13. Wadah, S.T.; Murakami, T. Chemical studies of the contents of alsophila-spinulosa tryon. Chem. Pharm. Bull. 1985, 33, 4182-4187.

14. Xiao, M.; Cao, N.; Fan, J.J.; Shen, Y.; Xu, Q. Studies on flavonoids from the leaves of Linderaaggregate. J. Chin. Med. Mat. 2011, 34, 62-64.

15. Niemi, P.; Tamminen, T.; Smeds, A.; Viljanen, K.; Ohra-aho, T.; Holopainen, M.U.; Faulds, C.B.; Poutanen, K.; Buchert, J. Characterization of lipids and lignans in brewer's spent grain and its enzymatically extracted fraction. J. Agric. Food. Chem. 2012, 60, 9910-9917. 
16. Shuuji, H.; Hikaru, O.; Kunihide, M. Gas-liquid chromatographic separation of aldose enantiomers as trimethylsilyl ethers of methyl 2-(polyhydroxyalkyl)-thiazolidine-4(r)carboxylates (organic,chemical). Chem. Pharm. Bull. 1987, 35, 501-506.

17. Barrero, A.F.; Haïdour, A.; Dorado, M.; Cuerva, J.M. Two sesquilignans from the wood of Abiesmarocana. Phytochemistry 1996, 41, 605-609.

18. Smeds, A.I.; Eklund, P.C.; Sjöholm, R.E.; Willför, S.M.; Nishibe, S.; Deyama, T.; Holmbom, B.R. Quantification of a broad spectrum of lignans in cereals, oilseeds, and nuts. J. Agric. Food. Chem. 2007, 55, 1337-1346.

19. Yoshinari, K.; Shimazaki, N.; Sashida, Y.; Mimaki, Y. Flavanonexyloside and lignans from Prunus jamasakura bark. Phytochemistry 1990, 29, 1675-1678.

20. Tohru, K.; Satoko, M.; Shigetoshi, K.; Takaaki, T. Studies on the constituents of medicinal and related plants in Sri Lanka. III. Novel sesquilignans from Hedyotis lawsoniae. Chem. Pharm. Bull. 1985, 33, 1444-1451.

21. Abe, F.; Yamauchi, T.; Wan, A.S. Sesqui-, sester-and trilignans from stems of Cerbera manghas and C. odollam. Phytochemistry 1988, 27, 3627-3631.

22. Gao, M.L.; Zhang, Y.L.; Lin, S. Glycosides from the root of Iodes cirrhosa. J. Nat. Prod. 2008, 71, 647-654.

23. Huo, C.; Liang, H.; Zhao, Y.; Wang, B.; Zhang, Q. Neolignan glycosides from Symplocos caudata. Phytochemistry 2008, 69, 788-795.

24. Liao, S.G.; Wu, Y.; Yue, J.M. Lignans from Wikstroemia hainanensis. Helv. Chim. Acta 2006, 89, 73-80.

25. Mossmann, T.J. Rapid colorimetric assay for cellular growth and survival: application to proliferation and cytotoxicity assays. J. Immunol. Meth. 1983, 65, 55-63.

Sample Availability: Samples of the compounds 1-9 are available from the authors.

(C) 2014 by the authors; licensee MDPI, Basel, Switzerland. This article is an open access article distributed under the terms and conditions of the Creative Commons Attribution license (http://creativecommons.org/licenses/by/3.0/). 